\title{
TANGGUNG JAWAB PELAKU USAHA TERHADAP MAKANAN TANPA TANGGAL KADALUARSA
}

\author{
Stefanus Klinsi Hermanto \\ Fakultas Hukum Universitas Katolik Darma Cendika \\ Email: hermanto1.steven@gmail.com
}

\begin{abstract}
Abstrak
Tanggal, bulan dan tahun kadaluarsa merupakan batas akhir suatu makanan dijamin mutunya sepanjang penyimpanannya mengikuti petunjuk yang diberikan oleh produsen (best before). Tanggal kadaluarsa umumnya dicantumkan dilabel suatu produk pangan yang ditempatkan di tempat yang mudah dilihat dan dijangkau oleh konsumen. Pencantuman tanggal kadaluarsa pada produk makanan dan minuman merupakan salah satu bentuk informasi pangan dari produsen kepada konsumen yang wajib disertakan pada setiap produk yang akan pasarkan. Pencatuman tanggal kadaluarsa perlu lebih diperhatikan oleh produsen, karena dengan produsen memperhatikan pencamtuman tanggal kadaluarsa maka produsen telah mematuhi Peraturan Pemerintah No. 69 Tahun 1999 tentang Label dan Iklan Pangan serta produsen ikut andil dalam melindungi konsumen. Tujuan penelitian ini adalah untuk mengetahui Efektifitas Peraturan Pemerintah tentang Tanggal Kadaluarsa dan Jaminan Pertanggung jawaban Pelaku Usaha terhadap Konsumen. Metode penelitian yang digunakan adalah yuridis empiris, yaitu penelitian hukum yang dilakukan dengan cara melakukan wawancara atau data primer sebagai bahan pokok untuk diteliti. Hasil penelitian menunjukkan Pertama, Pengaturan tanggal kadaluarsa berdasarkan Peraturan Pemerintah No. 69 Tahun 1999 tentang Label dan Iklan Pangan belum memberikan hasil yang efektif karena masih terdapat pelaku usaha yang tidak mencantumkan tanggal kadaluarsa pada label kemasan pangan; kedua, Adanya itikad baik yang tergolong tinggi dari pelaku usaha toko oleh-oleh di kawasan Surabaya Timur untuk bertanggung jawab mengenai makanan yang tidak memiliki tanggal kadaluarsa walaupun masih terdapat beberapa pelaku usaha yang tidak bersedia memberikan ganti rugi kepada konsumennya.
\end{abstract}

Kata kunci: tanggal kadaluarsa; pelaku usaha; konsumen.

\section{Abstract}

Date, month and year of expiration is the deadline for a quality guaranteed food as long as it is stored following the instructions given by the manufacturer (best before). The expiration date is generally listed on the label of a food product placed in a place that is easily seen and reached by 
consumers. Inclusion of expiration dates on food and beverage products is one form of food information from producers to consumers that must be included on every product to be marketed. The inclusion of the expiration date needs to be given more attention by the producers, because with the producers paying attention to the inclusion of the expiration date the producer has complied with Government Regulation No. 69 of 1999 concerning Food Labels and Advertisements which is producers took part in protecting consumers. The purpose of this study was to determine the Effectiveness of Government Regulations on Expiry Date and Business Responsibility Guarantee for Consumers. The research method used is empirical juridical, namely legal research carried out by conducting interviews or primary data as a staple for research. The results of the study show that, first, the setting of the expiration date based on Government Regulation No. 69 of 1999 concerning Food Labels and Advertisements have not provided effective results because there are still producers that not put an expiration date on food packaging labels; secondly, there is a high level of good intention from souvenir shops in East Surabaya to be responsible for food that does not have an expiration date, although there are still some producers who are not willing to provide compensation to consumers.

Keywords: expiration date; producers; consumers.

\section{Pendahuluan}

Kota Surabaya merupakan ibukota provinsi Jawa Timur dan menjadi kota terbesar kedua setelah Jakarta. Sebagai kota metropolis, Surabaya menjadi pusat bisnis, perdagangan, industri maupun pendidikan sehingga hal tersebut menjadikan Surabaya sebagai tempat berkunjung untuk melakukan berbagai aktivitas, baik bisnis maupun pendidikan. Selain itu, Surabaya juga dikenal dengan sejarahnya, sehingga memiliki beberapa obyek wisata yang berhubungan dengan sejarah masa lampau, misalnya monumen-monumen maupun museum. Mengingat bahwa Surabaya sebagai tempat berkunjungnya masyarakat luar baik untuk bisnis, wisata, maupun pendidikan, maka dimanfaatkan oleh pelaku usaha untuk meraup rupiah dengan membuka berbagai jenis usaha, salah satunya ialah toko oleh-oleh.

Toko oleh-oleh harus memiliki Surat Ijin Usaha Perdagangan (SIUP) yang dikeluarkan oleh Dinas Perdagangan kota Surabaya. Hal ini bertujuan untuk menciptakan iklim usaha yang kondusif dan memberikan jaminan kepastian hukum kepada usaha yang dijalankan, sehingga dapat meningkatkan kepercayaan konsumen. Dengan adanya SIUP, pelaku usaha harus mentaati 
peraturan yang telah ditetapkan oleh pemerintah, salah satunya dengan mencantumkan tanggal kadaluarsa pada kemasan produk makanan maupun minuman sesuai dengan perundang-undangan yang berlaku. Pencantuman tanggal, bulan dan tahun kadaluarsa pada produk makanan dan minuman merupakan salah satu bentuk informasi pangan dari produsen kepada konsumen yang wajib disertakan pada setiap produk yang akan dipasarkan. Informasi tersebut merupakan bentuk perlindungan kesehatan bagi konsumen.

Undang-Undang Dasar Negara Republik Indonesia Tahun 1945 Pasal 28D secara eksplisit telah mengatur mengenai tanggal kadaluarsa pada produk makanan, yang menyatakan bahwa; "setiap orang berhak atas jaminan, perlindungan, serta kepastian hukum. Pencantuman tanggal kadaluarsa pada suatu produk pangan merupakan salah satu bentuk jaminan produsen atau pelaku usaha kepada konsumen". Berdasarkan Pasal 1 angka 1 Undang-Undang No. 8 Tahun 1999 tentang Perlindungan Konsumen yang selanjutnya disebut UUPK, yang dimaksud dengan perlindungan konsumen adalah segala upaya yang menjamin adanya kepastian hukum untuk memberi perlindungan kepada konsumen. Salah satu bentuk kepastian hukum yang dimaksud dalam UUPK tersebut adalah adanya pencantuman tanggal kadaluarsa pada makanan maupun minuman. Sedangkan pada Peraturan Pemerintah No 69 Tahun 1999 tentang Label dan Iklan Pangan yang selanjutnya disebut PP Label dan Iklan Pangan, Pasal 27 ayat (1) menyebutkan bahwa: tanggal, bulan dan tahun kadaluarsa pangan wajib dicantumkan secara jelas pada label kemasan pangan.

Pencantuman tanggal, bulan dan tahun kadaluarsa pada produk makanan dan minuman merupakan salah satu bentuk informasi pangan dari produsen kepada konsumen yang wajib disertakan pada setiap produk yang akan pasarkan. Informasi tersebut merupakan bentuk perlindungan kesehatan bagi konsumen. Informasi tentang pangan merupakan bagian yang penting bagi manusia, karena selama manusia hidup membutuhkan pangan dan hal ini tidak dapat dipungkiri bahwa pangan merupakan kebutuhan mendasar bagi setiap manusia karena hal ini sangat berpengaruh pada keberlangsungan hidup manusia. ${ }^{1}$

Berdasarkan data kinerja tahun 2018 Balai Besar Penjamin Obat dan Makanan di Surabaya yang selanjutnya disebut BBPOM Surabaya, telah melakukan pemeriksaan terhadap 385 sarana distribusi makanan dengan hasil $264(68,57 \%)$ sarana Memenuhi Ketentuan (MK), 121 (31,43\%) sarana Tidak Memenuhi Ketentuan (TMK) karena menjual pangan kadaluarsa, menjual

${ }^{1}$ Aulia Muthiah, Hukum Perlindungan Konsumen Dimensi Hukum Postif dan Ekonomi Syariah, Pustaka Baru Press, Yogyakarta, 2018. hlm. 140. 
produk yang TMK label dan menjual pangan tanpa izin edar ${ }^{2}$. Dari data tersebut dapat dilihat bahwa masih banyak pelaku usaha yang tidak mematuhi ketentuan BPOM.

Dinas Perindustrian dan Perdagangan (Disperindag) Jawa Timur juga melakukan upaya dalam meminimalisasi peredaran makanan yang tidak memenuhi ketentuan. Dalam sidak yang dilakukan dibeberapa tempat di Surabaya oleh Disperindag ditemukan berbagai jenis makanan kering yang dijual tanpa menyertakan izin produksi, izin edar dan tidak adanya tanggal kadaluarsa. Selain itu, masyarakat sebagai konsumen juga mempunyai peranan penting untuk memberikan informasi terkait dengan pelaku usaha yang menjual produk makanan yang tidak memenuhi ketentuan. Masyarakat dituntut untuk lebih cermat dan cerdas sebelum membeli produk makanan. Melalui informasi atau laporan yang diberikan oleh konsumen, maka dinasdinas terkait dapat segera melakukan tindakan sehingga tidak menimbulkan kerugian bagi konsumen lainnya. Saat ini telah banyak layanan pengaduan konsumen sebagai bentuk keseriusan pemerintah dalam menindak pelaku usaha yang tidak sesuai dengan peraturan perundang-undangan serta memberikan perlindungan bagi konsumen.

Hal tersebut menunjukkan bahwa banyaknya produsen atau pelaku usaha yang tidak mementingkan keselamatan konsumen dan hanya mementingkan keuntungan belaka. Hal ini dapat kita lihat dengan banyaknya kasus pelanggaran-pelanggaran yang dilakukan oleh oknum pelaku usaha kepada pihak konsumen. Salah satunya dengan tidak mencantumkan tanggal kadaluarsa pada produk meskipun telah secara jelas diatur dalam PP Label dan Iklan Pangan.

Tidak adanya tanggal kadaluarsa pada produk makanan menimbulkan ketidakpastian batas kelayakan makanan dapat dikonsumsi oleh tubuh. Akibatnya apabila mengonsumsi makanan yang tidak segar pada umumnya ialah gangguan pencernaan, seperti diare dan muntah. Efeknya tergantung pada beberapa hal yaiitu, usia, jumlah makanan yang dikonsumsi, serta apabila konsumen memiliki masalah kesehatan lain yang dideritanya. ${ }^{3}$

Abdul Haris Hamid dalam bukunya yang berjudul Hukum Perlindungan Konsumen Indonesia menyatakan bahwa, pelaku usaha dan konsumen saling membutuhkan, sebab tanpa adanya konsumen tidak mungkin pelaku usaha dapat menjalankan usahanya, begitupula dengan konsumen yang bergantung

2 “Laporan Tahunan 2018 Balai Besar Pengawas Obat dan Makanan di Surabaya”, www.pom. go.id/new/admin/dat/2019/0515/Laporan_Tahunan_BBPOM_Surabaya_2018_Edited-min.pdf, diakses pada tanggal 26 November 2019.

3"Ternyata, Boleh Makan Makanan yang Sudah Expired", https://www.guesehat.com/ternyata-boleh-makan-makanan-yang-sudah-expired, diakses pada tanggal 27 Maret 2020. 
kepada pelaku usaha dalam memenuhi kebutuhanya. ${ }^{4}$ Kecurangan yang dilakukan pelaku usaha, menimbulkan kerugian bukan hanya terhadap konsumen melainkan juga kepada pelaku usaha yang melakukan kegiatan usahanya dengan jujur dan bertanggung jawab. Sehingga menimbulkan pemikiran negatif dari konsumen tentang pelaku usaha yang selalu memikirkan keuntungan pribadi dan tidak mementingkan konsumen.

\section{Permasalahan}

Berdasarkan pada latar belakang diatas, maka permasalahan yang akan dibahas adalah sebagai berikut, Bagaimana pengaturan tanggal kadaluarsa berdasarkan Peraturan Pemerintah No. 69 Tahun 1999 tentang Label dan Iklan Pangan ? Bagaimana tanggung jawab pelaku usaha toko oleh-oleh di kawasan Surabaya Timur terhadap makanan tanpa tanggal kadaluarsa?

\section{Metode Penelitian}

Metode yang digunakan dalam penelitian ini adalah yuridis empiris, yaitu penelitian hukum yang dilakukan dengan cara melakukan wawancara atau data primer sebagai bahan pokok untuk diteliti dengan menentukan narasumber yang berkaitan dengan permasalahan yang diteliti.

Pendekatan yang digunakan dalam penelitian ini adalah pendekatan socio legal. Pendekatan soscio legal adalah mengidentifikasi dan mengkaji hukum positif sebagai institusi sosial yang nyata. ${ }^{5}$ Pendekatan socio legal adalah menekankan penelitian dengan tujuan memperoleh pengetahuan hukum secara empiris yang tertuju langsung ke obyeknya yaitu perspektif konsumen mengenai tanggal kadaluarsa berdasarkan Peraturan Pemerintah No. 69 Tahun 1999 tentang Label dan Iklan Pangan.

\section{Pembahasan}

\section{Pengaturan Tanggal Kadaluarsa berdasarkan Peraturan Pemerintah Nomor 69 Tahun 1999 tentang Label dan Iklan Pangan}

Label merupakan sumber informasi yang terperinci bagi konsumen karena di dalamnya memuat representasi, peringatan, maupun instruksi dari suatu produk. Informasi dari pelaku usaha berupa nama produk, komposisi, berat bersih, tanggal kadaluarsa, sangat dibutuhkan oleh konsumen sebelum membeli suatu produk dan memiliki pengaruh daya beli yang besar bagi konsumen ${ }^{6}$. Menurut Peraturan Pemerintah No. 69 Tahun 1999 tentang Label

\footnotetext{
${ }^{4}$ Abdul Haris Hamid, Hukum Perlindungan Konsumen Indonesia, Sah Media, Makassar, 2017. hlm. 89.

${ }^{5}$ Jonaedi Efendi dan Johnny Ibrahim, Metode Penelitian Hukum, Prenadamedia group, Depok, 2018. hlm. 153.

${ }^{6}$ Aulia Muthiah, Op.Cit, hlm. 139-140.
} 
dan Iklan Pangan, yang selanjutnya disebut sebagai PP Label dan Iklan Pangan pada Pasal 1 angka (3) menerangkan bahwa pengertian label pangan adalah setiap keterangan mengenai pangan yang berbentuk gambar, tulisan, kombinasi keduanya atau bentuk lain yang disertakan pada pangan, dimasukan kedalam, ditempelkan pada, atau merupakan bagian kemasan pangan. Konsumen dapat secara cermat menentukan pilihan sebelum membeli dan/atau mengkonsumsi suatu produk pangan melalui informasi yang terdapat pada label pangan.

Pasal 3 ayat (2) PP Label dan Iklan Pangan, keterangan label, sekurangkurangnya memuat:

a. Nama produk;

b. Daftar bahan yang digunakan

c. Berat bersih atau isi bersih;

d. Nama dan alamat pihak yang memproduksi atau memasukan pangan ke dalam wilayah Indonesia;

e. Tanggal, bulan, dan tahun kadaluarsa.

Pengertian tanggal, bulan dan tahun kadaluarsa ini telah mengalami perubahan, karena dalam Peraturan Menteri Kesehatan Nomor 346/Men.Kes/Per/IX/1983, pengertian tanggal kadaluarsa ialah batas waktu akhir suatu makanan dapat digunakan sebagai makanan manusia (use by date), sedangkan dalam Peraturan Menteri Kesehatan Republik Indonesia No. 180/MEN.KES/PER/IV/1985 pengertian tanggal, bulan dan tahun kadaluarsa ialah batas akhir suatu makanan dijamin mutunya sepanjang penyimpanannya mengikuti petunjuk yang diberikan oleh produsen (best before $)^{7}$. Tanggal kadaluarsa pada beberapa produk dibedakan menjadi best before dan use by. Best before artinya tanggal yang tercantum merupakan batas suatu produk masih layak dikonsumsi meskipun telah melewati batas tanggal yang tertera, namun produk telah mengalami penurunan kualitas. Sedangkan use by artinya batas tanggal dimana produk makanan tersebut tidak dapat lagi dikonsumsi ${ }^{8}$. Dengan adanya perbedaan tersebut menimbulkan kerancuan bagi masyarakat, karena masyarakat tidak banyak yang mengetahui perbedaan tersebut.

Agar pangan yang beredar di masyarakat terjamin mutu dan kualitasnya, maka pelaku usaha harus mentaati ketentuan sesuai dengan peraturan yang berlaku, salah satunya memberikan label keterangan produk termasuk tanggal kadaluarsa. Bagi pelaku usaha yang tidak mentaati peraturan tersebut, maka

7 Ahmadi Miru, Prinsip-Prinsip Perlindungan Hukum Bagi Konsumen Di Indonesia, Rajawali pers, Jakarta, 2011. hlm. 195.

8 I Nyoman Sucipta et.al, Pengemasan Pangan Kajian Pengemasan Yang Aman, Nyaman, Efektif dan Efisien, Udayana university press, Denpasar, 2017. hlm. 106. 
akan dikenakan sanksi administratif sesuai dengan Pasal 61 ayat (2) PP Label dan Iklan Pangan yaitu:

a. Peringatan secara tertulis;

b. Larangan untuk mengedarkan untuk sementara waktu dan atau perintah untuk menarik produk pangan dari peredaran;

c. Pemusnahan pangan jika terbukti membahayakan kesehatan dan jiwa manusia;

d. Penghentian produksi untuk sementara waktu;

e. Pengenaan denda paling tinggi Rp 50.000.000,00 (lima puluh juta rupiah), dan atau;

f. Pencabutan izin produksi atau izin usaha.

Undang-Undang No. 18 Tahun 2012 tentang Pangan, yang selanjutnya disebut sebagai UU Pangan, telah sangat jelas mengatur mengenai pencantuman label ini. UU Pangan ini dibentuk dengan tujuan untuk menyediakan pangan yang beraneka ragam dan memenuhi persyaratan keamanan, mutu dan gizi untuk dikonsumsi masyarakat. Pencantuman label yang menerangkan tanggal kadaluarsa diterapkan guna menjamin keamanan dan mutu suatu produk makanan.

Pangan yang diperdagangkan dalam negeri wajib mencantumkan label pada kemasannya, hal ini sesuai dengan Pasal 97 ayat (1) UU Pangan, mengatur bahwa; "setiap orang yang memproduksi pangan dalam negeri untuk diperdagangkan wajib mencantumkan label didalam dan/atau pada kemasan pangan". Sedangkan dalam Pasal 97 ayat (3) UU Pangan mengatur bahwa:

Pencantuman label ditulis atau dicetak dengan menggunakan bahasa Indonesia serta memuat paling sedikit keterangan mengenai:

a. Nama produk;

b. Daftar bahan yang digunakan;

c. Berat bersih atau isi bersih;

d. Nama dan alamat pihak yang memprouksi atau mengimpor;

e. Halal bagi yang dipersyaratkan;

f. Tanggal dan kode produksi;

g. Tanggal, bulan, dan tahun kadaluarsa;

h. Nomor izin edar bagi pangan olahan;

i. Asal usul bahan pangan tertentu.

Ketentuan mengenai pemberian tanggal kadaluarsa diatas tersebut hanya berlaku untuk makanan yang telah dikemas dan siap untuk diperdagangkan. Ketentuan tanggal kadaluarsa ini tidak berlaku untuk perdagangan makanan yang dibungkus dihadapan konsumen, misalnya pedagang makanan ringan yang menjual dan membuat produknya langsung dihadapan konsumen.

Agar tetap menjamin kualitas mutu makanan dan tidak menimbulkan kerugian bagi konsumen, maka setiap label tanggal kadaluarsa tidak boleh 
dihapus, dicabut, ditutup, diganti, melabel kembali dan/atau menukar tanggal bulan tahun kadaluarsa, hal ini sesuai dengan ketentuan pada Pasal 99 UU Pangan. Sanksi bagi pelanggar Pasal 99 UU Pangan, diatur dalam Pasal 143 UU Pangan yang menyatakan: Setiap orang yang dengan sengaja menghapus, mencabut, menutup, mengganti label, melabel kembali dan/atau menukar tanggal, bulan, tahun kadaluarsa pangan yang diedarkan sebagaimana dimaksud dalam Pasal 99 dipidana dengan pidana penjara paling lama 2 (dua) tahun atau denda paling banyak Rp 4.000.000.000,00 (empat milliar rupiah).

\section{Tanggung Jawab Pelaku Usaha Toko Oleh-Oleh Dikawasan Surabaya Timur} Terhadap Makanan Tanpa Tanggal Kadaluarsa

Pasal 1 angka 3 UUPK yang dimaksud dengan pelaku usaha adalah setiap orang perseorangan atau badan usaha, baik yang berbentuk badan hukum maupun bukan badan hukum yang didirikan dan berkedudukan atau melakukan kegiatan dalam wilayah hukum negara Republik Indonesia, baik sendiri maupun bersama-sama melalui perjanjian menyelenggarakan kegiatan usaha dalam berbagai bidang ekonomi.

Pelaku usaha dikelompokkan menjadi Investor, Produsen dan Distributor. Investor ialah pelaku usaha yang menyediakan dana bagi sebuah usaha. Produsen ialah pelaku usaha yang membuat, memproduksi barang dan/atau jasa. Sedangkan Distributor ialah pelaku usaha yang memperdagangkan barang dan/atau jasa kepada konsumen. ${ }^{9}$

Terdapat 3 tahapan dalam melakukan transaksi yaitu, tahap pra transaksi, tahap transaksi dan tahap purna transaksi. Tahap purna transaksi adalah tahap setelah terjadinya transaksi antara pelaku usaha dengan konsumen, yang kemudian diikuti dengan pemenuhan hak dan kewajiban masing-masing pihak. Dalam tahap ini terdapat kepuasan atau kekecewaan konsumen terhadap produk yang diperolehnya, sehingga kewajiban pelaku usaha dalam tahap ini ialah menyediakan layanan bagi konsumen untuk menyampaikan saran dan kritiknya bagi pelaku usaha.

Berdasarkan data yang diperoleh penulis dari 22 pelaku usaha toko oleh-oleh di kawasan Surabaya Timur, hanya sebesar $45 \%$ atau sebanyak 10 pelaku usaha toko oleh-oleh yang menyediakan layanan pengaduan bagi konsumen, sedangkan 55\% atau sebanyak 12 pelaku usaha toko oleh-oleh tidak menyediakan layanan pengaduan bagi konsumen. Hal tersebut menunjukan masih rendahnya pelayanan pelaku usaha toko oleh-oleh dikawasan Surabaya Timur terhadap konsumen, dengan kata lain pelaku usaha hanya mementingkan dirinya sendiri untuk mencari keuntungan tanpa memberikan perhatian kepada konsumennya.

\footnotetext{
${ }^{9}$ Agus Riyanto, Hukum Bisnis Indonesia, Batam Publisher, Batam, 2018. hlm 109.
} 
Berdasarkan data yang diperoleh dari 22 Pelaku usaha toko oleh-oleh di kawasan Surabaya Timur, sebanyak $91 \%$ atau sejumlah 20 pelaku usaha toko oleh-oleh di kawasan Surabaya Timur tidak pernah menerima laporan mengenai makanan tanpa tanggal kadaluarsa di toko, sedangkan $9 \%$ atau sejumlah 2 pelaku usaha toko oleh-oleh di kawasan Surabaya Timur pernah menerima laporan mengenai makanan tanpa tanggal kadaluarsa di toko tersebut. Hal tersebut menunjukan bahwa masih terdapat pelaku usaha yang menjual makanan tanpa tanggal kadaluarsa pada tokonya walaupun prosentase yang ditunjukan hanya sebesar $9 \%$ atau sebanyak 2 pelaku usaha toko oleh-oleh di kawasan Surabaya Timur akan tetapi perbuatannya tersebut menimbulkan keresahan bagi konsumen maupun pelaku usaha lainnya, hal ini terbukti berdasarkan data yang diperoleh penulis, bahwa pelaku usaha yang pernah menerima laporan mengenai makanan tanpa tanggal kadaluarsa yang dijualnya, menerima laporan sebanyak 1-3 kali. Dengan adanya laporan dari konsumen tersebut diharapkan agar pelaku usaha bersedia bertanggung jawab atas perbuatannya dan lebih teliti dalam memperjual-belikan produknya.

Tidak dicantumkannya tanggal kadaluarsa pada produk pangan yang di perdagangkannya merupakan perbuatan yang dilarang dalam peraturan perundang-undangan. Tanggal kadaluarsa merupakan batas keamanan suatu pangan dapat dikonsumsi sehingga dengan tidak adanya tanggal kadaluarsa, tidak dapat memberikan kepastian keamanan pangan bagi konsumen. Berdasarkan hal tersebut, maka pelaku usaha harus bertanggung jawab atas semua kesalahan yang diperbuatnya baik karena kelalaian maupun kesengajaan yang mengakibatkan kerugian bagi konsumen baik secara materiil maupun immateriil.

Bahwa didalam unsur kesalahan yang diperbuat oleh pelaku usaha, harus memenuhi salah satu syarat pentingnya yaitu: ${ }^{10}$

1. Unsur kesengajaan;

2. Unsur kelalaian;

3. Tidak ada alasan pembenar atau alasan pemaaf.

Menurut Munir Fuady mengenai unsur kesengajaan dan unsur kelalaian, perbuatan melawan hukum dengan kelalaian lebih ringan derajatnya dibandingkan dengan perbuatan melawan hukum dengan kesengajaan. Apabila seseorang yang dengan sengaja merugikan orang lain (baik untuk kepentingan pribadi maupun bukan) perbuatan tersebut merupakan perbuatan melawan hukum dalam arti yang serius dibandingkan dengan hanya kelalaian belaka. ${ }^{11}$

${ }^{10}$ Hetty Panggabean, Perlindungan Hukum Praktik Klinik Kebidanan, CV Budi Utama, Yogyakarta, 2018. hlm. 152.

${ }^{11}$ Ibid., hlm. 153. 

yaitu: ${ }^{12}$

Unsur kesengajan dalam suatu perbuatan terbagi menjadi 3 (tiga) bagian

1. Adanya unsur kesadaran (state of mind) dalam tindakannya;

2. Adanya konsekuensi atau akibat dari perbuatan; dan

3. Kesadaran dalam melakukan sehingga menimbulkan konsekuensi atau akibat.

Tindakan pelaku usaha yang tidak mencantumkan tanggal kadaluarsa merupakan bentuk pelanggaran terhadap aturan perundang-undangan. Schutznorm theorie mengajarkan bahwa perbuatan yang bertentangan dengan kaidah hukum dan karenanya merupakan perbuatan melawan hukum, akan menyebabkan pelaku usaha dapat dipertanggung jawabkan atas kerugian yang disebabkan oleh tindakan tersebut. ${ }^{13}$ Berdasarkan teori tersebut pelaku usaha yang menjual produk pangannya dengan tidak memenuhi kaidah perundang-undangan yang berlaku, maka pelaku usaha dapat dipertanggung jawabkan atas kelalaiannya tersebut baik disengaja maupun tidak.

Berdasarkan hasil wawancara peneliti dengan 22 pelaku usaha toko oleh-oleh di kawasan Surabaya Timur mengenai adanya pertanggung jawaban pelaku usaha terhadap konsumen yang dirugikan dengan tidak dicantumkan tanggal kadaluarsa pada produk yang dijualnya, 73\% atau sejumlah 16 pelaku usaha toko oleh-oleh di kawasan Surabaya Timur menyatakan memberi ganti rugi apabila ada konsumen yang dirugikan terkait tidak dicantumkannya tanggal kadaluarsa pada produk yang dijual dan 27\% atau sejumlah 6 pelaku usaha toko oleh-oleh di kawasan Surabaya Timur menyatakan tidak memberi ganti rugi apabila ada konsumen yang dirugikan terkait tidak dicantumkannya tanggal kadaluarsa pada produk yang dijualnya.

Berdasarkan data yang diperoleh dari 73\% atau sejumlah 16 pelaku usaha dari 22 pelaku usaha toko oleh-oleh di kawasan Surabaya Timur, bentuk ganti kerugian yang diberikan ada beberapa macam yaitu, sejumlah $58 \%$ atau sebanyak 15 pelaku usaha menyatakan memberi ganti rugi dalam bentuk menukar barang dengan barang yang memiliki tanggal kadaluarsa atau memenuhi standar, sejumlah 34\% atau sebanyak 9 pelaku usaha menyatakan memberi ganti rugi dalam bentuk mengembalikan uang konsumen yang telah dibayarkan atas suatu produk yang dibelinya sehingga menimbulkan kerugian bagi konsumen dan sejumlah $8 \%$ atau sebanyak 2 pelaku usaha menyatakan memberi ganti rugi dalam bentuk jaminan biaya perawatan kesehatan apabila konsumen yang membeli produknya menderita kesehatan karena mengkonsumsi produknya.

12 Ibid.

${ }^{13}$ Tanti Jatiningrum, Perbuatan Melawan Hukum yang Dilakukan Oleh Penguasa (Studi Putusan Kasasi No. 2121/K/PDT/2013), Skripsi, Universitas Indonesia, Depok, 2016. 
Tindakan pelaku usaha dengan menjual makanan tanpa tanggal kadaluarsa pada makanan produksinya maupun pada makanan yang bukan produksinya merupakan perbuatan yang bertentangan dengan pasal 8 ayat (1) huruf g UUPK yang menyatakan bahwa "Pelaku usaha dilarang memproduksi dan/atau memperdagangkan barang dan/atau jasa yang tidak mencantumkan tanggal kadaluarsa atau jangka waktu penggunaan/pemanfaatan yang paling baik atas barang tertentu". Sedangkan pasal 9 PP Label dan Iklan Pangan menyatakan bahwa "Setiap orang yang memproduksi atau memasukkan ke dalam wilayah Indonesia pangan yang dikemas untuk diperdagangkan, dilarang mencantumkan label yang tidak memenuhi ketentuan sebagaimana dimaksud dalam Peraturan Pemerintah ini". Pelanggaran terhadap peraturan tersebut diatur dalam pala 61 PP Label dan Iklan Pangan yang menyatakan bahwa:

1. Setiap orang yang melanggar ketentuan-ketentuan sebagaimana dimaksud dalam Peraturan Pemerintah ini dikenakan tindakan administratif;

2. Tindakan administratif sebagaimana dimaksud pada ayat (1) meliputi :

a. Peringatan secara tertulis;

b. Larangan untuk mengedarkan untuk sementara waktu dan atau perintah untuk menarik produk pangan dari peredaran;

c. Pemusnahan pangan jika terbukti membahayakan kesehatan dan jiwa manusia

d. Penghentian produksi untuk sementara waktu;

e. Pengenaan denda paling tinggi Rp. 50.000 .000 (lima puluh juta rupiah), dan atau;

f. Pencabutan izin produksi atau izin usaha.

3. Pengenaan tindakan administratif sebagaimana dimaksud dalam ayat (2) huruf b, c, d, e, dan f hanya dapat dilakukan setelah peringatan tertulisa sebagaimana dimaksud pada ayat (2) huruf a diberikan sebanyak-banyaknya tiga kali.

4. Pengenaan tindakan administratif sebagaimana dimaksud dalam ayat (2) dan ayat (3) hanya dapat dilakukan oleh Menteri teknis sesuai dengan kewenangan berdasarkan masukan dari Menteri Kesehatan.

Prinsip tanggung jawab mutlak (strict liability) merupakan dasar pertanggung jawaban bagi konsumen, sehingga konsumen tidak diwajibkan lagi untuk membuktikan kesalahannya pelaku usaha, hal ini dikarenakan dalam prinsip ini dasar adanya pertanggung jawaban bukanlah kesalahan melainkan pelaku usaha langsung bertanggung jawab sebagai risiko. ${ }^{14}$

\footnotetext{
${ }^{14}$ Aulia Muthiah, Op.Cit, hlm. 136.
} 


\section{Penutup}

\section{Simpulan}

Pengaturan tanggal kadaluarsa berdasarkan Peraturan Pemerintah No. 69 Tahun 1999 tentang Label dan Iklan Pangan belum memberikan hasil yang efektif karena masih terdapat pelaku usaha yang tidak mencantumkan tanggal kadaluarsa pada label kemasan pangan.Adanya itikad baik dari sebagian besar pelaku usaha toko oleh-oleh di kawasan Surabaya Timur untuk bertanggung jawab mengenai makanan yang tidak memiliki tanggal kadaluarsa. Itikad baik tersebut didapatkan berdasarkan data yang diperoleh penulis bahwa sebesar 73\% dari 22 pelaku usaha toko oleh-oleh di kawasan Surabaya Timur bersedia menyatakan memberi ganti rugi apabila ada konsumen yang dirugikan terkait tidak dicantumkannya tanggal kadaluarsa pada produk yang dijual.

\section{Saran}

Kepada para pelaku usaha toko oleh-oleh di kawasan Surabaya Timur wajib mentaati Peraturan Pemerintah No. 69 Tahun 1999 tentang Label dan Iklan Pangan dan/atau peraturan perundang-undangan lainnya agar penerapan peraturan dapat berjalan secara efektif dan pelaku usaha memberikan layanan konsumen untuk menampung keluhan serta siap untuk bertanggung jawab atas kerugian yang diderita konsumen akibat kelalaian pelaku usaha dalam menajalankan usahanya.

\section{Daftar Pustaka}

\section{Buku}

Abdul Haris Hamid, Hukum Perlindungan Konsumen Indonesia, Sah Media, Makassar, 2017.

Agus Riyanto, Hukum Bisnis Indonesia, Batam Publisher, Batam, 2018.

Ahmadi Miru, Prinsip-Prinsip Perlindungan Hukum Bagi Konsumen Di Indonesia, Rajawali pers, Jakarta, 2011.

Aulia Muthiah, Hukum Perlindungan Konsumen Dimensi Hukum Postif dan Ekonomi Syariah, Pustaka Baru Press, Yogyakarta, 2018.

Hetty Panggabean, Perlindungan Hukum Praktik Klinik Kebidanan, CV Budi Utama, Yogyakarta, 2018.

I Nyoman Sucipta et.al, Pengemasan Pangan Kajian Pengemasan Yang Aman, Nyaman, Efektif dan Efisien, Udayana university press, Denpasar, 2017. Jonaedi Efendi dan Johnny Ibrahim, Metode Penelitian Hukum, Prenadamedia group, Depok, 2018. 


\section{Jurnal/Karya Ilmiah}

Tanti Jatiningrum, Perbuatan Melawan Hukum yang Dilakukan Oleh Penguasa (Studi Putusan Kasasi No. 2121/K/PDT/2013), Skripsi, Universitas Indonesia, Depok, 2016.

\section{Peraturan Perundang-Undangan}

Undang-Undang Dasar Negara Republik Indonesia Tahun 1945

Undang-Undang No. 8 Tahun 1999 tentang Perlindungan Konsumen

Undang-Undang No. 18 Tahun 2012 tentang Pangan

Peraturan Menteri Kesehatan Nomor 346/Men.Kes/Per/IX/1983

Peraturan Menteri Kesehatan Republik Indonesia

No.180/MEN.KES/PER/IV/1985

Peraturan Pemerintah No. 69 Tahun 1999 tentang Label dan Iklan Pangan

Internet

"Laporan Tahunan 2018 Balai Besar Pengawas Obat dan Makanan di Surabaya", www.pom.go.id/new/admin/dat/2019/0515/Laporan_Tahunan_BBPOM_S urabaya_2018_Edited-min.pdf, diakses pada tanggal 26 November 2019.

"Ternyata, Boleh Makan Makanan yang Sudah Expired", https://www.guesehat.com/ternyata-boleh-makan-makanan-yangsudah-expired, diakses pada tanggal 27 Maret 2020. 